\title{
A Review of the Correlation between Geology and Geothermal Energy in North-Eastern Nigeria
}

\author{
B. U. Abdullahi ${ }^{1}$; J. K. Rai ${ }^{1}$; O. M. Olaitan ${ }^{1}$; Y. A. Musa ${ }^{2}$ \\ Department of Physics, Kebbi State University of Science and Technology Aliero Nigeria \\ Department of Physics, Usmanu Danfodiyo University, Sokoto.
}

\begin{abstract}
Nigeria as a country is suffering from acute shortage of power supply for both industrial and domestic use. Most of the renewable energy sources are underutilized including geothermal sources. The wide range of geologic formations in the north-eastern Nigeria provides an avenue for exploration and exploitation of geothermal energy. Therefore this paper focuses on finding the possible geothermal reservoirs existing in Nigeria in order to help in solving the Nigeria's energy crisis. Geology and mineral maps were utilised using overlay method. Two volcanic points and one fumarole were identified and they were recommended to be suitable for geothermal energy generation.
\end{abstract}

Keywords: Geology; Geothermal; Energy; Chad Basin; Fumarole; Earth

\section{Introduction}

Geothermal Energy is thermal energy generated and stored in the earth. Thermal energy is the energy that determines the temperature of matter. The geothermal energy of the Earth's crust originates from the original formation of the planet (20\%) and from radioactive decay of minerals (80\%) (Schubert, 2002). The geothermal gradient which is the difference in temperature between the core of the planet and its surface drives a continuous conduction of thermal energy in the form of heat from the core to the surface.

Geothermal energy is a renewable, environmentally friendly energy-source based on the internal heat of the Earth. It may be associated with volcanic activity, hot crust at depth in tectonically active areas or permeable sedimentary layers at great depth (Lund, 2004). Thermal springs have been used for bathing; washing and cooking for thousands of years, while geothermal electricity production, and large-scale direct use, started during the first half of the twentieth century. Geothermal energy is now utilised in more than 50 countries worldwide.

With a rapidly growing world-population, and ever-increasing environmental concerns, sustainable development has become an issue of crucial importance for mankind (Tiwari, 2005). Geothermal resources have the potential of contributing significantly to sustainable energy use in many parts of the world. The production capacity of geothermal systems is quite variable and different systems respond differently to production, depending on their geological setting and nature. Therefore, comprehensive management is essential for the sustainable use of all geothermal resources.

Geothermal energy has been used for thousands of years in some countries for cooking and heating. The name geothermal comes from two Greeks words, Geo which means Earth and Thermal which means heat. Geothermal energy is defined as heat from the Earth. It is a clean, renewable resource that provides energy in the United States and around the world (Bertani, 2010). It is considered a renewable energy resource because the heat emanating from the interior of the Earth is essentially limitless. The heat continuously flowing from the Earth's interior is estimated to be equivalent to 42 million megawatts of power. 5 One megawatt is equivalent to 1 million watts, and can meet the power needs of about 1,000 homes. The interior of the Earth is expected to remain extremely hot for billions of year to come, ensuring an essentially limitless flow of heat. Geothermal power plants capture this heat and convert it to energy in the form of electricity.

Geothermal projects require access to water during several stages of development and operation. Some current geothermal exploration and development activity occurs in areas of low water supply potential and/or high water demand. However, water resources, and in particular groundwater resources, are still to be quantified in many parts of the world. Access rights to water for geothermal applications will therefore require careful management and discussion by both water planners and the geothermal industry.

At the core of the Earth, thermal energy is created by radioactive decay (Turcotte, 2002) and temperatures may reach over $5000^{\circ} \mathrm{C}\left(9,000^{\circ} \mathrm{F}\right)$. Heat conducts from the core to surrounding cooler rock. The high temperature and pressure cause some rock to melt, creating magma convection upward since it is lighter than the solid rock. The magma heats rock and water in the crust, sometimes up to $370^{\circ} \mathrm{C}\left(700^{\circ} \mathrm{F}\right)$, (Nemzer, 2010). From hot springs, geothermal energy has been used for bathing since Paleolithic times and for space heating since ancient Roman times, but it is now better known for electricity generation. Worldwide, about 10,715 megawatts(MW) of geothermal power is online in 24 countries. An additional 28 gigawatts of direct 
geothermal heating capacity is installed for district heating, space heating, industrial processes, desalination and agricultural applications, (Fridleifsson, 2013).

Geothermal electric plants were traditionally built exclusively on the edges of tectonic plates where high temperature geothermal resources are available near the surface. The development of binary cycle power plants and improvements in drilling and extraction technology enable enhanced geothermal systems over a much greater geographical range, (Jefferson, 2006). Demonstration projects are operational in Landau-Pfalz, Germany, and Soultz-sous-Forêts, France, while an earlier effort in Basel, Switzerland was shut down after it triggered earthquakes. Other demonstration projects are under construction in Australia, the United Kingdom, and the United States of America, (Bertani and Ruggero, 2009).

The thermal efficiency of geothermal electric plants is low, around $10-23 \%$, because geothermal fluids do not reach the high temperatures of steam from boilers. The laws of thermodynamics limit the efficiency of heat engines in extracting useful energy.

The centre of the Earth is around $6000^{\circ} \mathrm{C}$ easily hot enough to melt rock. Even a few kilometers down, the temperature can be over $250^{\circ} \mathrm{C}$ if the Earth's crust is thin. Geothermal has a higher capacity factor (a measure of the amount of real time during which a facility is used) than many other power sources. Unlike wind and solar resources, which are more dependent upon weather fluctuations and climate changes, geothermal resources are available 24 hours a day, 7 days a week. While the carrier medium for geothermal electricity (water) must be properly managed, the source of geothermal energy, the Earth's heat, will be available indefinitely.

A geothermal resource assessment shows that nine western states together have the potential to provide over 20 percent of national electricity needs. Although geothermal power plants, concentrated in the West, provide the third largest domestic source of renewable electricity after hydropower and biomass, they currently produce less than one percent of total U.S. electricity.

Geothermal energy is renewable, the energy keeps on coming as long as we don't pump too much cold water down and cool the rocks too much.

\section{Materials And Methods}

\subsection{Materials}

The materials used for this study include

1. Location map

2. Geology map

3. Mineral map

\subsubsection{Location Map}

The study area is located between latitudes $8^{0} 78 \mathrm{E}$ and $14^{0} 56 \mathrm{E}$ and longitudes $6^{0} 11$ and $14^{0} 33 \mathrm{~N}$. It comprises of Bornu, Yobe, Bauchi, Gombe, Adamawa and Taraba states. These six states represent the northeast geopolitical zone of Nigeria. The area is covered mostly by Chad (Bornu) basin, precambrian basement, upper Benue trough, Yolasubbasin and Gongolasubbasin.

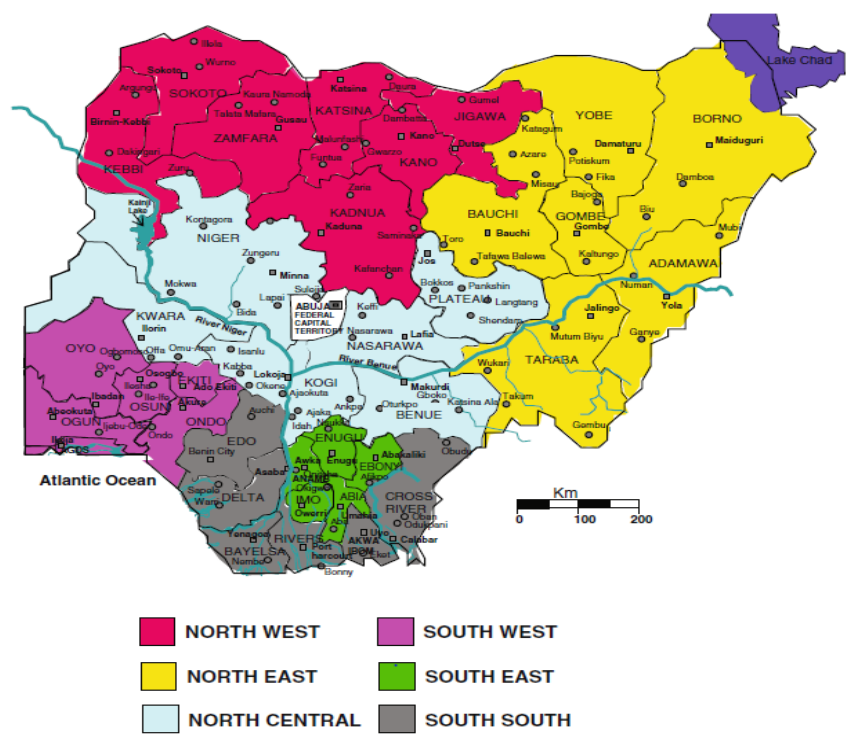

Fig 2.1 Geographical Map of Nigeria 


\subsubsection{Geology Map}

A geologic map represents the lithology and so far as possible the geologic age of every important geologic unit in a given area. Geology describes the regional geological structures of a given area. Each distinctive unit that can be shown effectively to the scale of the map is a geologic formation. A good topographic base map is essential for representing relations of bedrock to land surface forms. A complete geologic map would indicate important structural details such as inclinations of strata, locations of faults and axial traces of folds. Usually the map is supplemented by vertical sections on which structural features seen at the surface are projected to limited depths.

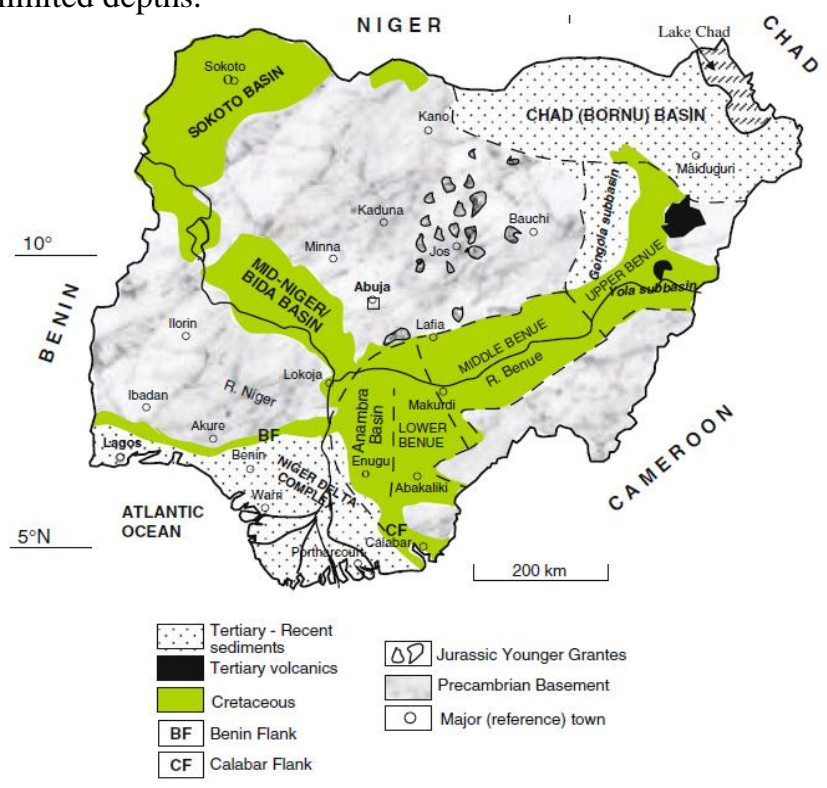

Fig 2.2 Geology Map of Nigeria

\subsubsection{Short Review of The Geology of The Chad Basin in Nigeria}

The geological evolution of the Bornu-Benue trough which constitutes the bulk of the study areas:

- $\quad$ Pre Trough setting.

- Mesozoic Pre-Albian magmatic and tectonic activity.

- $\quad$ Main phase of the Bornu-Benue Trough formation.

- The Santonian event.

- $\quad$ Post tectonic period.

Chad or Bornu Basin: The Chad basin is a basin located in the northeastern part of Nigeria. It cut across Bornu, Yobe, Gombe and Adamawa States, it comprises of different formations that were formed at different times. In tabular form, it can be described as in the table below.

Table 3.1Stratigraphic sequence in the Chad basin (Northeastern Nigeria)

\begin{tabular}{|l|l|l|}
\hline Age & Formation & Environment \\
\hline Pleistocene & Chad formation (unconformity) & Lacustrine strata \\
\hline Paleocene & Kerri Kerri Formation & Continental Strata \\
\hline Maestrichtian & Gombe Sandstone & Estuarine-deltaic strata \\
\hline Senonian & FikaShales & Marine strata \\
\hline Turonian & Gongila Formation & Marine-estuarine strata \\
\hline Cenomanian & Bima Sandstone (unconformity) & Continental strata \\
\hline
\end{tabular}

\section{Chad Formation}

This formation is a variable sequence that includes all Quaternary sediments of lacustrine origin underlying the surface deposits over a vast area $\left(\right.$ about $15,000 \mathrm{~km}^{2}$ ) in Kano, Bornu and Bauchi provinces (Barber, 1965). It also outcrops extensively in the Chad, Cameroon and Niger Republics. Without Nigeria, the Chad formation is exposed only on the southwestern margin of the basin. The Chad formation varies lithologically both laterally and vertically. It extends from the Gongola branch of the Benue Trough to the Chad Lake. It appears to be part of the trough system which developed in Central Africa during the cretaceous times (Elf Nigeria 1984). Few direct geological data are available on this basin and the structural pattern was obtained from the interpretation of available gravity and magnetic data. SLAR Imagery interpretation (Benkhelil, et al; 1985) has shown that the regional orientation of the Bornu basin is southwest-Northeast corresponding to an alignment of the deepest sub-basins. Tectonic similarities are found with the Benue Trough's main branch 
Southeast. Deep investigations (Elf Nigeria 1984) have revealed an early tectonic phase consisting of titled blocks and folds in the cretaceous tectonic phase. The deepest basins contain more than $4000 \mathrm{~m}$ of sediments. The upper formations (Tertiary) lie unconformably upon the deformed cretaceous sediments.

\section{Kerri Kerri Formation}

This formation rests unconformably on the folded cretaceous sediments. It consists of a continental sequence dipping northeast beneath the Chad formation. A thickness of about $220 \mathrm{~m}$ is known in the west and southwest of the Chad basin (Barber and Jones, 1960). These sediments are absent at Maiduguri and drilling proved that they wedge out between Maiduguri and the Damaturu-Gashua road.

\section{Gombe Sandstone}

The Gombe sandstone is a sequence of estuarine and deltaic sedimentation, best developed in the southwest portion of the basin where a thickness of at least $350 \mathrm{~m}$ has been reported. The formation gets thinner towards Lake Chad as drilling cores show only a thin layer of mudstones on top of the Fika Shales that is thought to represent the Gombe Sandstone.

An unconformity may exits below the Gombe Sandstone as suggested by differences in texture between this and the older cretaceous rocks. The Gombe sandstone is not strongly folded and does not show the east-west trends which are imposed on the earlier formations. The lower beds are characterized by mudstones and ironstones. The latter vary from a few centimeters to $2 \mathrm{~m}$ in thickness. They are vesicular or accretionary in structure, and are believed to have originated as a type of "ironpan" in extremely shallow water when sedimentation was almost at a standstill (Carter, et al;1963). The middle part of the Gombe Sandstone is composed of well-bedded sandstones and siltstones. Towards the top of the sequences, cross-bedded sandstones are present. The beds have been dated by palynological methods as upper maestrichtian to Paleocene.

\section{Fika Shales}

These are marine shales of Upper Turonian to Senonian age. They vary in thickness from 100m at the southwestern margins near potiskum to about 500m near Maiduguri in the Northeast. It may be suggested that the older Cretaceous beds also thicken towards the centre of the basin in similar manner. The Fika Shales consist of blue-black shales, occasionally gypsiferous with thin limestone intercalations Fish and reptile remains have been obtained and these suggest a Turonian to Maestrichtian age (Carter, et al; 1963).

\section{Gongila Formation}

This formation is a transitional sequence between the purely continental Bima sandstone and the marine Fikashales. It has a maximum thickness of nearly 500m (Reyment, 1965). The base of the formation is defined by the first appearance of marine limestone of above the Bima sandstone. This basal limestone of about $3 \mathrm{~m}$ in thickness consists of both non-fossiliferous and shelly varieties. Numerous ammonites of lower turonian age are present (Carter, et al; 1963).

\section{Bima Sandstone}

This formation is of probably upper Albian to lower Turonian age. It outcrops both in the Chad basin and the Benue basin, but the thickness of the formation is much reduced alon the Zumbuk ridge separating the two basins. The Bima sandstone directly overlies the crystalline basement unconformably. It varies in thickness from $100 \mathrm{~m}$ to over $3,000 \mathrm{~m}$. This wide variation in thickness may be due to the irregular relief of the crystalline floor and variable degree of deposition (Reyment, 1956).

\subsubsection{Mineral Map}

Minerals are the basic building blocks of rocks. About 3600 minerals have been identified, but fewer than 50 are common constituents in the types of rocks that are abundant in the Earth. The most common minerals in the crust are feldspars, quartz, micas, amphiboles, pryroxenes, olivine and calcite. Each mineral is characterized by a distinct geometric packing of its constituent atoms known as its crystal structure. Mineral map is used to represent the distributions of minerals over a geographical area. The mineral map of Nigeria as shown in this work below had clearly indicated the distributions of solid minerals over all the 36states of Nigeria. 
Table 3.2 list of solid minerals in the northeastern states of Nigeria.

\begin{tabular}{|l|l|l|l|l|l|}
\hline $\mathbf{1}$ & Kaolin & Bauchi & $\mathbf{9}$ & Columbite & Bauchi, \\
\hline $\mathbf{2}$ & Coal & Adamawa,Bauchi, Gombe, & $\mathbf{1 0}$ & Cassiterite & Bauchi \\
\hline $\mathbf{3}$ & Rutile & Bauchi, & $\mathbf{1 1}$ & Diatomite & Borno, Yobe \\
\hline $\mathbf{4}$ & Gypsum & Adamawa, Gombe, yobe & $\mathbf{1 2}$ & Fluorite & Bauchi, Taraba \\
\hline $\mathbf{5}$ & Feldspar & Bauchi, Borno & $\mathbf{1 3}$ & Magnesite & Adamawa \\
\hline $\mathbf{6}$ & Clay & In all the states federation & $\mathbf{1 4}$ & Wolframite & Bauchi \\
\hline $\mathbf{7}$ & Ilmenite & Bauchi, & $\mathbf{1 5}$ & Gemstones & Bauchi, Taraba \\
\hline $\mathbf{8}$ & Limestone & Gombe, & $\mathbf{1 6}$ & Baryte & Taraba \\
\hline
\end{tabular}

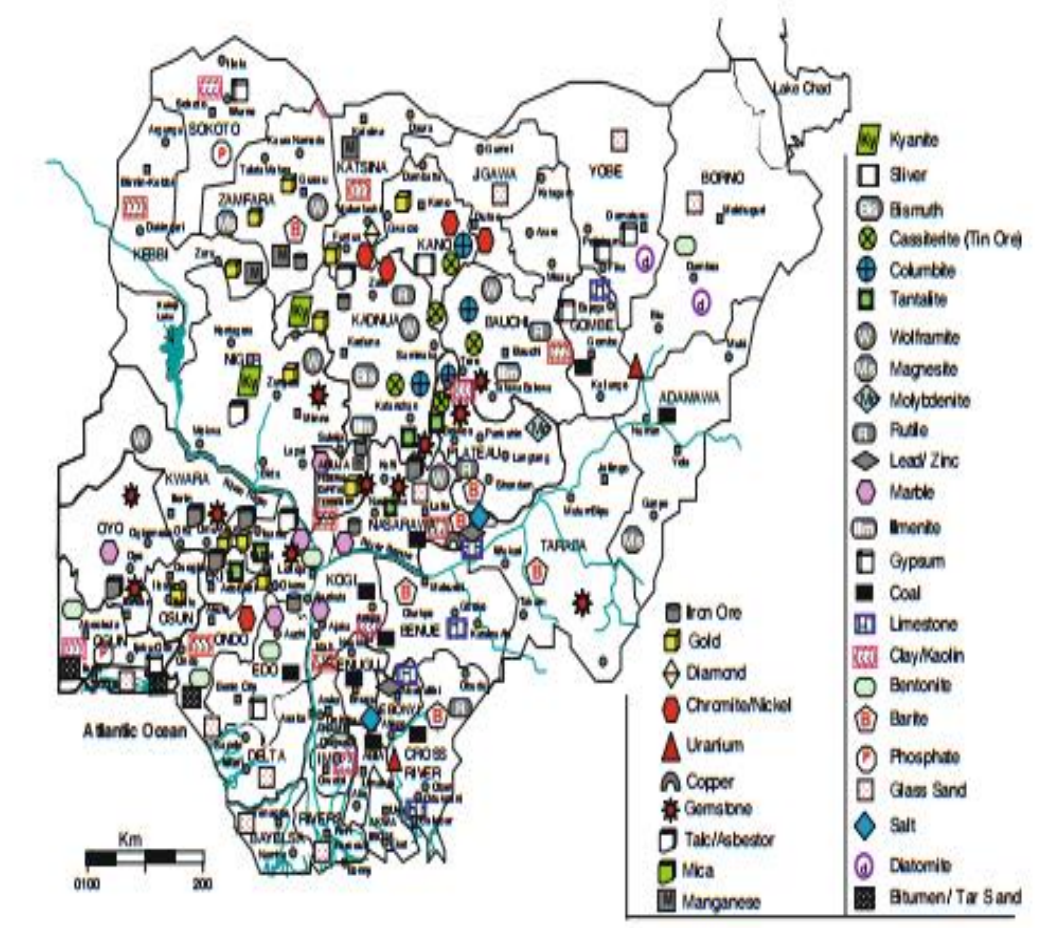

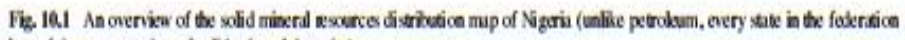

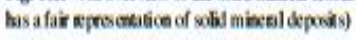

\subsubsection{Volcanicity}

Fig 2.3 Mineral Map of Nigeria

This is defined as the process that is associated with the transfer of magma and volatiles from the interior of the Earth to its surface. Current volcanicity is confined to regions of the Earth where lithospheric plates converge, diverge, or pass over possible mantle hot-spots.

Naturally occurring large areas of hydrothermal resources are called geothermal reservoirs. Most geothermal reservoirs are deep underground with no visible clues showing above ground. However, geothermal reservoir sometimes finds its way to the surface in the form of volcanoes and fumaroles (holes where volcanic gases are released), hot springs, and geysers. The most active geothermal resources are usually found along major plate boundaries where earthquakes and volcanoes are concentrated. Most of the geothermal activity in the world occurs in an area called the Ring of Fire that encircles the Pacific Ocean (Jefferson, 2006). However, volcanic eruptions comes along with the deposition of various elements and or chemical compounds just as fumaroles release a lot of gaseous materials which constitute various chemical compounds. Therefore, occurrence of volcanoes as well as such chemicals in an area especially if it's along a plate boundary will suggest a good geothermal source.

\subsection{Methodology}

The method employed for this study is overlay of the different maps to study the correlation between the different geologic units and comparative analysis of the different chemical compounds occurring in the study area with some geological features such as volcanoes and fumaroles to ascertain the strength of their relationships which will eventually help in recommending the expected geothermal reservoirs within the study area. Geothermal gradients for the various points were analyzed to see commonalities and differences. 


\subsection{Results}

\section{Results And Discussions}

After a careful review of the various geological anc mineral maps, the result shows that there are three geothermal points in the study area, one in form of volcanoes and the other in the form of fumarole.

\subsubsection{Volcanicity}

The Cenozoic volcanic activity in northeastern Nigeria began with the intrusion into the Benue trough of a trachyte-phonolite suite of plugs 22-11 m.y. ago. Later activity, which was more widespread and dominantly basaltic in character, began some $7 \mathrm{~m}$.y. ago and has continued until very recent times. It resulted in basaltic plugs and lava plateau within the Benue trough, and cinder cones and lavas on the Jos Plateau.

The Cenozoic volcanic activity in north-eastern Nigeria is probably related to the nearby Cameroun volcanic line. The concentration of plugs within the Benue trough may reflect internal adjustments along old lines of weakness within the African lithosphere plate, in response to synchronous changes affecting the plate's external dimensions and internal structure, such as the growth of the Red Sea and the Gulf of Aden, and the volcanism of the east African rift valley (Obaje, 2009).

Based on the overlay of geology map and location map of northeastern states of Nigeria as well as assessment of various reports from NESREA and NASRDA on volcanic activities in Nigeria, the following findings were made;

\section{Chad Basin}

The Chad Basin which is located on Lake Chad is the largest inland basin in Africa occupying an area of approximately 2,500, $000 \mathrm{~km} 2$ extending over parts of the Republic of Niger, Chad, Sudan and the northern portions of Cameroon and Nigeria. The Nigerian sector of the Chad Basin (Fig. 1) covers about 152, $000 \mathrm{~km} 2 \mathrm{of}$ territory in Bornu, Bauchi, Plateau and Kano states and constitutes only about $6.5 \%$ of the entire basin (Oteze and Fayose, 1988). The basin contains about $4.65 \mathrm{~km}$ of marine and continental sediments made up of the Bima Sandstone, Gongila Formation, Fika Shale, Kerri Kerri and Chad Formations (Okosun, 2000). The basin is rimmed by crystalline basement rocks mainly of granitic and gneissic compositions with some mica schists. Basalts, minor basic and acidic intrusions (particularly of Tertiary age) occur commonly within parts of the basin as sills and plugs. These intrusions (sill and plugs) on Tertiary rocks could change the heat flow and temperature (Nwankwo, et al. 2009). They influence the geothermal gradient of the Chad Basin. No rocks of Paleozoic age outcrop in the Nigerian sector of the Chad Basin but it is believed that these sediments may be preserved in the lower depressions and grabens, which characterize the basin's floor topography (Zarma, 2004).

\section{Biu Plateau}

The Biu Plateau is a highland area in Northeastern Nigeria containing many recently extinct volcanoes. It covers about $5,200 \mathrm{~km}^{2}(2,000 \mathrm{sq} \mathrm{mi})$ and has an average elevation of $700 \mathrm{~m}(2,300 \mathrm{ft})$ (Francis, 1971). The plateau lies between the Upper Benue Basin to the south and the Chad Basin to the north. High points are Wade Hill at $775 \mathrm{~m}$ (2,543 ft) above sea level and Wiga Hill, at well over $800 \mathrm{~m}(2,600 \mathrm{ft})$. The plateau is the source of many tributaries of the Gongola River, which have cut deep gorges. To the north, the plateau slopes gently to the Bauchi plains and the Chad Basin (Obaje, 2009).

There is evidence of early volcanic activity in the area during the Cretaceous, which ended about 65 million years ago (Taylor and Francis, 1971) However, the plateau was built around the end of the Miocene, and the bulk of the rocks are Pliocene basalts that have erupted from small vents or fissures, and then spread in a thin layer over wide areas. Activity resumed in the Quaternary with thin flows of lava issuing from small cinder cones and filling the valleys. Most of the basalts date between 7 and 2 million years ago, but some are less than a million years old. The plateau includes many small pyroclastic cones caused by explosions when water penetrated downward and came into contact with fresh lava (Obaje, 2009). There are a number of wellpreserved volcanic cones rising above the Plateau along a NNW-SSE axis in the Miringa volcanic zone. It is very possible that the volcanic activity in the Biu Plateau is associated with the activity in the Cameroon line to the south (Rankenburg, et al; 2004).

Basaltic lava plateaus, trachyte plugs and domes, large central volcanoes and small basalt cinder cones with thin flows are all found among the more southerly manifestations of Cenozoic volcanism in West Africa (Wright, 1985). This province also includes the remarkable offshore continuation of the Cameroon volcanic line, the four islands situated in the Gulf of Guinea itself. Areas of basement doming include the Jos Plateau, southeast of the Benue Trough, with probably still greater uplifts; and the Adamawa Highlands further east, where lavas of the Ngaoundere Plateau overlie the Ngaoundere fault zone, which was reactivated in the Cretaceous. The flood basalts of the Biu Plateau are situated on the Zambuk Ridge of the Upper Benue Trough, and the smaller Longuda Plateau lies near the bifurcation of the Upper Benue Trough, which has been identified as a possible secondary triple junction. 
The geothermal gradient in the Biu plateau is very scanty as no proper complete research is available for the area. This may be due to the assertion that the volcanic rocks in the area are dormant because no eruption is recorded recently despite their large number (up to eighty). However, some research is in progress using the temperature measured during pumping tests.

\section{Pindiga Formation}

Pindiga formation is located in Gombe state of Nigeria. Recently some kind of volcanic activity occured in the said formation. Emissions of some kind, possibly including toxic/environmentally harmful gases, have apparently been taking place in the Abaduguri range in Funakaye Local Government Area. North-eastern Nigeria does have a history of active volcanism (although how recently the area was active is not known) so the idea isn't intrinsically unlikely. Descriptions of the supposed current activity, however, are rather baffling.

According to NESREA (2011) the rock which has been emitting smoke in the past seven months, was a sign of "a dormant volcano which may erupt in future". This can be considered to be a result of the impact of an earthquake that occurred in Pindiga formation, Gombe State, hundreds of years ago'. This suggests the dormant volcano in the area is likely to erupt any time. The gas has apparently been gushing out from the rocky area for seven or eight months.

The smoke emanating from the rock was a result of the impact of an earthquake that occurred in Pindiga formation, Gombe State hundreds of years ago. he suggest that there is a trace of an earthquake in Pindiga formation which has a link with Abadaguri rocky range. Data obtained from the office of the Nigerian Meteorological Agency in Gombe State shows that the volcanic eruption that is currently taking place in a rock in Ndanijam Kargo Village in Funakaye local government as extinct or dormant.

\subsubsection{Fumaroles \\ Wikki Warm Spring}

The manifestation of geothermal reservoirs in Nigeria is not only in the form of volcanoes but also in the form of fumaroles (warm springs). One of the known geothermal resource areas (KGRA) in Nigeria is the Wikki warm springs of Bauchi State. It flows from Gombe sandstone in Yankari game reserve. TIt is a surficial effusion resulting from the circulation of water to great depths through faults in the basement complex rocks of the area. Positive Bouguer gravity anomalies were also found parallel to this trough and are interpreted to indicate shallow mantle. The temperature is about $32^{\circ} \mathrm{C}$ which suggest that temperatures beneath are relatively higher.

\subsection{Discussion}

So far, we have seen that a number of potential geothermal reservoirs existed in the northeastern states of Nigeria, at different locations and in different forms either as volcanoes or as fumaroles (warm springs). These points are scattered in both the precambrian basement complex region as well as the tertiary (recent) sediments. Geologically, the Wikki warmspring is in the precambrian basement complex which falls under the southwestern part of the Chad basin and geopolitically in Bauchi state of northeastern Nigeria while the Biu plateau falls under the tertiary sediment of the eastern part of the basin and geopolitically cuts across both Bornu, Gombe as well as Adamawa states of Nigeria. However, no any correlation was found between geothermal existences and mineral occurance as such the existing chemical elements or compounds found in the northeastern Nigeria has no any correlation with geothermal reservoirs. With the discovery of potential geothermal sources in the northeastern part of Nigeria, proper and well planned exploration/exploitation can be made in order to increase the country's total energy output. This can be done using any feasible method depending on the type of source.

\subsubsection{Geothermal Power Generation}

Most geothermal projects are based on a mixture of steam and hot water requiring single or double flash systems to separate out the hot water. However; high-enthalpy geothermal fields are only available in areas with volcanic activity, whereas the rest of the fields are low or medium enthalpy resources. Geothermal power generation is currently based on three technology options (Long, et al; 2003) that are briefly illustrated as follows.

1.Dry Steam Plants: Dry steam plants commonly use condensing turbines. The condensate is re-injected (closed cycle) or evaporated in wet cooling towers. A typical geothermal plants capacity is 50-60MW, but more recently 110-MWplants have been commissioned and are currently in operation (EGEC, 2009). Only the Italian geothermal fields of Larderello and the Geysers in the United States provide vapour-dominated fluids (Renner, 2002). However, the conversion devices consist of geothermal steam turbines that are designed to make effective use of the comparatively low-pressure and high-volume fluid produced in such conditions. 


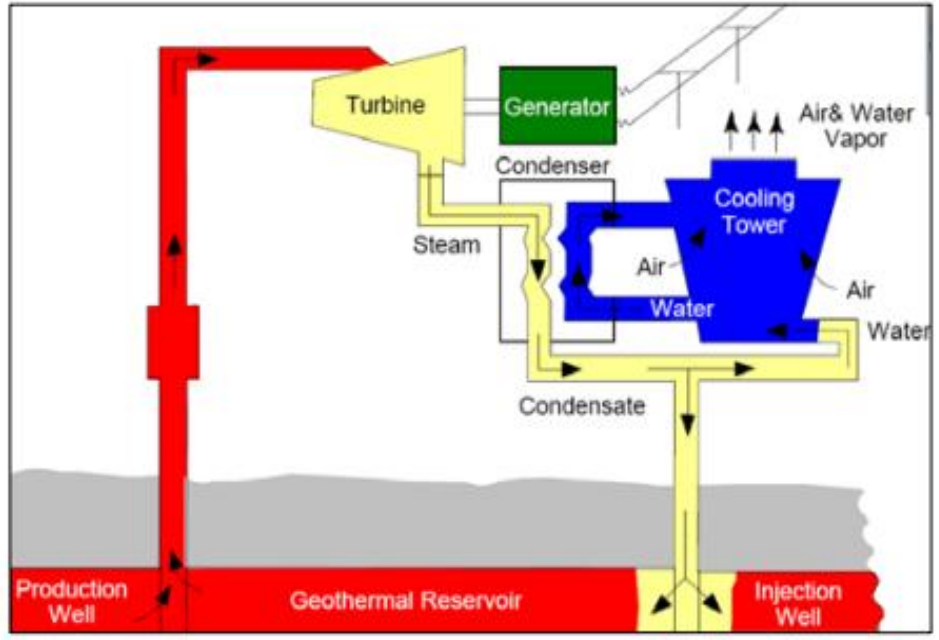

Fig 4.1 Direct steam geothermal power plant (Sanner, 2007)

2.Flash Steam Plants: this is similar to the dry steam plants; geothermal flash plants are used to extract energy from high-enthalpy geothermal resources, in which, the steam is obtained from a separation process (flashing). The steam is then routed to the turbines and the resulting condensate is routed to re-injection or further flashing at lower-pressure. The fluid fraction exiting the separators, as well as the steam condensate (except for condensate evaporated in a wet cooling system) is usually re-injected. The typical size of flash plants is between 2 and 45MWe (DiPippo, 1999).

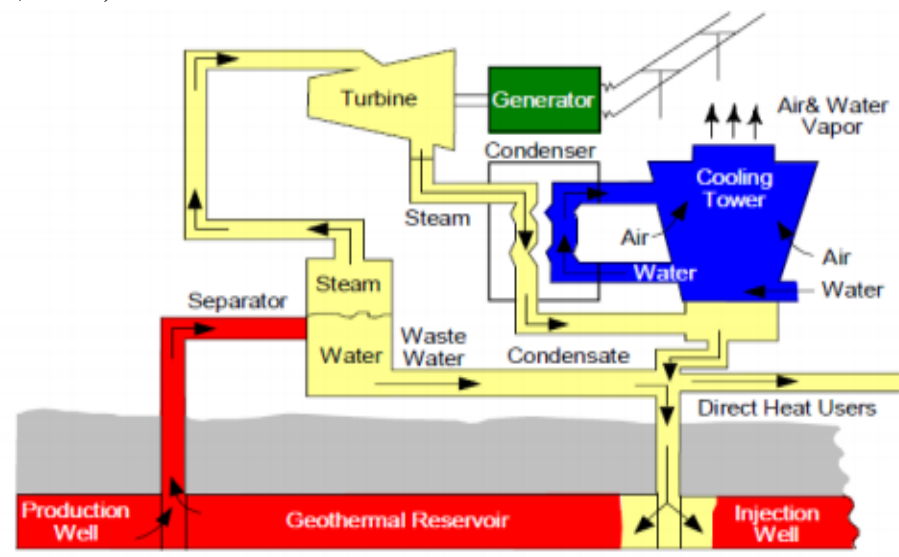

Fig 4.2 flash Steam Geothermal Power Plant (Kutscher, 2004)

3.Binary Cycle Plants: This type is used to produce electricity from hot groundwater reservoirs where the percent of water is too greater than steam and their heat is not enough to transfer a great part of hot water to steam. Also they are used to produce electricity from hot groundwater reservoirs with high saltiness where there is great part can't be transformed into steam because of high availability of solid precipitated substances and can be also used for hot water which contains high percent of gases. Binary plantsare usually applied to low-or medium-enthalpy geothermal fields where the resource fluid is used, via heat exchangers, to heat a process fluid in a closed loop. The process fluid (e.g. ammonia/water mixtures used in kalina cycles or hydrocarbons in organic Rankine cycles, ORC) has physical properties (i.e. boiling and condensation points) that better match to the geothermal resource temperature (Köhlerand Saadat, 2003). In the binary plants, the exhaust resource fluids are often re-injected in the field along with all the original constituents. Therefore, these plants are true zerodischarge technologies. The typical size of binary plants is less than 5MW(DiPippo, 1999). 


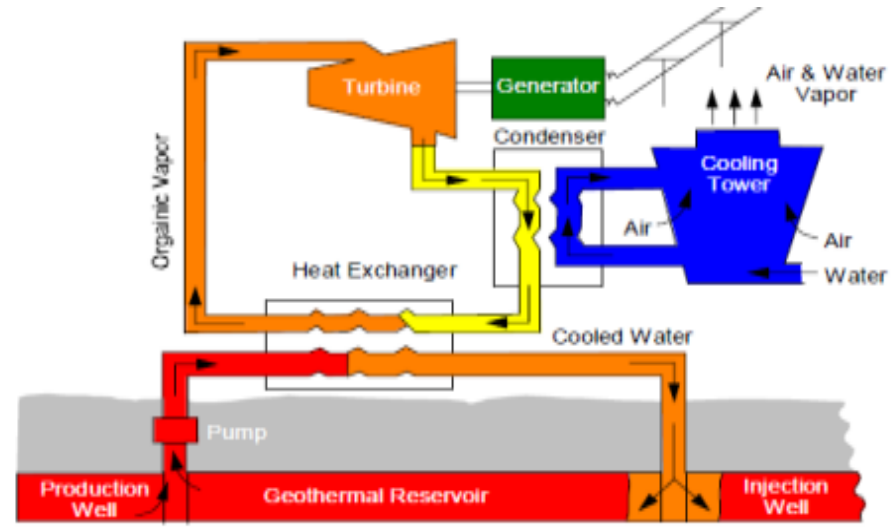

FIG 4.3 Binary Cycle geothermal Power Plant (Kutscher, 2004)

From the above, we can see that the first two methods can be applied to both Biu and Pindiga formations due to their volcanic nature whereas the last method is best suited for Wikki warm spring which is a hot groundwater source.

\section{Conclusion}

Based on the available information extracted from the geology and mineral maps of Nigeria, three major potential geothermal sources were found; two are volcanicin nature (i.e. Biu plateau and Pindiga formation) while the other is a fumarole warm spring (i.e. Wikki warm springs). The two volcanic points represent a shallow depth to the mantle and can provide (if exploited) an enormous amount of energy for generation of electricity while the other point (Wikki warm springs) will provide enormous amount of water for heating and other domestic purposes. However, the northeastern Nigeria, with its multiple geologic formations which many believe has a relation with Cameroun line to the south (Rankenburg, et al; 2004). Therefore, it is hoped that if explored more, more geothermal reservoirs will be found.

Considering the result obtained above and the geothermal potential of the northeastern Nigeria, I recommend the following;

1. That more geological exploration should be carried out in the study area in order to reveal the details that are not currently available.

2. That with the multiple nature of the geology of the northeastern part of Nigeria, much is needed from government in terms of investment in order to harness the geothermal potentials therein.

3. That multinational companies can be invited to invest in the geothermal exploration/ exploitation in the northeastern part of Nigeria.

4. That quantitative evaluation should be done to evaluate the performance of each source and the percentage it can contribute to the national grid.

\section{References}

[1]. Barber, W. (1965).Pressure Water in the Chad Formation of Bornu and Dikwa Emirates, North- Eastern Nigeria.Geol, Surv.Nigeria Bull.No. 35, 138.

[2]. Barber, W.,\& Jones, D.G. (1960). The Geology and Hydrology of Maiduguri, Bornu Provinces

Eastern Nigeria.Geol, 5-20.

[3]. Benkhelil, J. C. (1985). Structural interpretation of the Benue trough and Borno Basin. Geological interpretation of Gravity and Aeromagnetic data. Elf Nigeria Ltd, Exploration Department, p.59.

[4]. Bertani, R. (2010). 'Geothermal Power Generation in the World 2005-2010 Update Report', $\quad$ Proceedings World Geothermal Congress 2010, Bali, Indonesia, 25-29 April 2010.

[5]. Bertania \& Ruggero. (2009)."Geothermal Energy: An Overview on Resources and Potential", International Conference on National Development of Geothermal Energy Use, Slovakia.

[6]. Carter, J.D., Barber, W. \&Tait, E. A. (1963).the geology of parts of Adamawa, Bauchi and Bornu Provinces in Northeastern Nigeria. Geol, Surv.Nigeria Bull.No. 30, 109p.

[7]. Fridleifsson, B., \& Ingvar. (2013). "Science Direct-Renewable and Sustainable Energy Reviews: Geothermal energy for the benefit of the people". Retrieved 25-02-2013.

[8]. Jefferson, W., \& Tester.(2006). The Future of Geothermal Energy, Impact of Enhanced Geothermal Systems (EGS) on the United States in the 21st Century: An Assessment, Idaho Falls: Idaho National Laboratory, Massachusetts Institute of Technology, pp. 1-8 to 1-33. Retrieved 26-02-2013.

[9]. Lund, J. (2004). "100 Years of Geothermal Power Production", Geo-Heat Centre Quarterly Bulletin (Klamath Falls, Oregon: Oregon Institute of Technology) 25 (3): 11-19, Retrieved 27-03-2013.

[10]. Nemzer, J. (2010). "Geothermal heating and cooling".

[11]. NESREA (2011), Annual report on hazardous geological activities in nigeria. pp 256

[12]. Obaje, N. G. (2009). 'Geology and Mineral Resources of Nigeria' Nasarawa State University Dept. Geology and Mining Keffi Nigeria.p.50. 
[13]. Rankenburg, K., Lassiter, J., \&Brey, G. (2004). 'The role of continental crust and lithospheric mantle in the Genesis of Cameroon Volcanic Line Lavas: Constraints from Isotropic Plateau'. Journal of Petrology 46 (1): 169-190. Retrieved 25-07-2013.

[14]. Reyment, R.A. (1956). On the stratigraphy and paleontology of the Cretaceous of Nigeria and West Africa.Geol. Foren, stockh, Forh, 78, p.17-96.

[15]. Reyment, R.A. (1965). ZurStammesentwick lung der Ammoniteng ettungen Gombeoceras Reyment and Pseudotissodia Peron.Neues Jb. Geol. Palaont., Mb. 11, p. 520-524. Aspects of the Geology of Nigeria. Univ. of Ibadan press, 145.

[16]. Taylor \& Francis.(1971). West Africa, Volume 25, Part 1.p. 285.

[17]. Tiwari, G.N. \& Ghosal, M.K. (2005).Renewable Energy Resources: Basic Principles and Applications, Alpha Science.

[18]. Turcotte, D.L.,\& Suhubert, G. (2002). Geodynamics.Cambridge University Press, pp. 136-137.

[19]. Wright JB and McCurry P (1970) First occurrence of Manganese ores in Northern Nigeria. Econ Geol 65,103-106 